\title{
Izaak Duwan-Torcow i praska grupa MChT (MChAT) w Republice Czechosłowackiej w okresie między wojennym
}

\author{
Petr Kaleta \\ Uniwersytet Masaryka w Brnie, Wydział Pedagogiczny \\ Katedra Historii
}

\section{The Karaite actor Isaak Douvan-Tortsov and the Prague group MAT (MAAT) in the interwar Republic of Czechoslovakia}

\begin{abstract}
Summary: Isaak Douvan-Tortsov, an actor and director of Karaite origin, was one of the leading figures in Russian theater at the beginning of the $20^{\text {th }}$ century. Like many other representatives of Russian culture, Douvan-Tortsov emigrated following the Civil War, spending time in many countries both in Europe and elsewhere. In the 1920s, Douvan had the opportunity, via the Moscow Art Theater Prague Group, to travel to Czechoslovakia, where he spent several months and devoted himself to theater work. Isaak Douvan-Tortsov spent time in Prague at the end of 1925 and the beginning of 1926, primarily in the Vinohrady Municipal Theatre, but he also visited other cities in what was then Czechoslovakia for MAT (MAAT) performances, as was mentioned in news stories from the time. The text deals predominantly with this thus far unknown period of Douvan's life.
\end{abstract}

Key words: Isaak Douvan-Tortsov, the Prague group of the Moscow Art Theatre (MAT/MAAT), Karaites, interwar Czechoslovakia 


\section{Wstęp}

Wiele osób pochodzenia karaimskiego osiągnęło znaczące sukcesy w życiu zawodowym na polu oświaty, kultury, nauki, czy też piastując funkcje państwowe. Warto przy tym pamiętać, że istniała też niewielka grupa Karaimów, którzy związali się z teatrem i zyskali międzynarodową renomę w tej dziedzinie kultury. Należał do nich przede wszystkim aktor i reżyser Izaak Duwan-Torcow, na którego karierę teatralną znaczny wpływ wywarła rosyjska wojna domowa. Lata dwudzieste XX wieku były dla niego okresem podróży po krajach Europy, a także za ocean, gdzie miał możliwość występowania jako aktor na tamtejszych scenach teatralnych. W tym czasie w ramach działalności praskiej grupy Moskiewskiego Teatru Artystycznego zawitał do Republiki Czechosłowackiej, gdzie przebywał i występował przez kilka miesięcy. W niniejszym artykule skupiamy się przede wszystkim na związkach Duwana-Torcowa z działalnością rosyjskich grup teatralnych w Pradze i innych miastach Czechosłowacji. Jako podstawowe źródło informacji o aktywności Duwana-Torcowa w Czechosłowacji zostały wykorzystane nieliczne dokumenty zachowane w Archiwum Narodowym w Pradze, a także artykuły i doniesienia ówczesnej prasy.

\section{Życie i twórczość Duwana-Torcowa}

Izaak Ezrowicz Duwan urodził się w 1873 roku w Eupatorii w rodzinie znanego karaimskiego działacza społecznego, kupca drugiej gildii i wpływowego filantropa, Ezry Izaakowicza Duwana (1844-1906). O pozycji rodziny Duwanów i poważaniu, jakim cieszyła się w Eupatorii, świadczą koligacje: dziadkiem po kądzieli Izaaka był pierwszy karaimski hacham, Sima Solomonowicz Babowicz (1790-1855). Wybitną postacią był również jego starszy brat, Siemion Ezrowicz Duwan (1870-1957), działacz społeczny i wieloletni burmistrz Eupatorii.

Izaak Duwan najpierw uczęszczał do miejskiego gimnazjum 4-klasowego w rodzinnym mieście, po czym naukę w wyższych klasach kontynuował w gimnazjum w Symferopolu. Następnie zapisał się na wydział prawa Uniwersytetu w Kijowie. Studia ukończył w 1896 r., wtedy też rozpoczął pracę jako prawnik. W 1899 roku zdał egzamin na aplikanta adwokackiego przy Kijowskiej Izbie Sądowej, a w 1901 roku został członkiem palestry kijowskiego okręgu sądowego. Kariera prawnicza nie pociągała go jednak na tyle, aby pozostał w tym zawodzie. ${ }^{1}$

$1 \quad$ Kazas, Mihail Mihailovič i in. (red.), Karaimskaâ narodnaâ ènciklopediâ. Tom 5. Kul'tura krymskih karaimov (tûrkov). Sankt-Peterburg 2006, s. 277. 
Duwan swoje życie poświęcił teatrowi, z którym zetknął się już w wieku szkolnym. Jako student występował w przedstawieniach teatralnych Kijowskiego Stowarzyszenia Dramatycznego, przez dwa sezony grał także w Kijowskim Teatrze Kolejowym. W 1901 r. do swojej grupy teatralnej zaprosił go znany reżyser i impresario, Nikołaj Nikołajewicz Sołowcow, u którego następnie Duwan występował przez dwa sezony, w Kijowie i Odessie. Wówczas udawało mu się jeszcze łączyć teatr z praktyką prawniczą, ale wkrótce okazało się to niemożliwe, dlatego stopniowo rezygnował z wykonywania wyuczonego zawodu, by bez reszty móc się poświecić karierze aktorskiej. W 1903 r. dołączył do trupy teatru działającego przy kijowskim Komitecie Piśmienności (ros. Общество грамотности), prowadzonego przez Michaiła Matwiejewicza Borodaja. Wkrótce i sam Duwan zaczął działać jako impresario. Zorganizował Teatr Miejski w Wilnie, w którym zadebiutował jako główny reżyser, a jednocześnie przygotowywał przedstawienia w wileńskim Teatrze Narodowym. W 1905 r. powrócił do Kijowa, gdzie poprowadził wspomniany teatr przy Komitecie Piśmienności, a przez ponad rok także teatr Sołowcowa. ${ }^{2}$

Ze względu na problemy zdrowotne porzucił działalność jako impresario i poświęcił się wyłącznie karierze aktorskiej. Na scenie wcielał się w postać komika-komentatora (ros. комик-резонер). Jego aktorstwo, niezależnie od komicznego charakteru repertuaru, wyróżniało się niezwykłą szlachetnością tonu. W związku z karierą sceniczną Duwan zaczął używać pseudonimu Torcow, który po niedługim czasie stał się dopełnieniem jego nazwiska: Duwan-Torcow.

Poza aktorstwem udzielał się także jako pedagog w Szkole Dramatycznej Kijowskiego Towarzystwa Sztuki i Literatury. Szybko się stał uznaną osobistością w aktorskim świecie. W 1912 roku został zaproszony do pracy w grupie aktorskiej Moskiewskiego Teatru Artystycznego (Московский Художественный театр). W ten sposób rozpoczął się nowy etap jego życia artystycznego. W swoim pierwszym sezonie teatralnym w MChT zagrał pięć ról, między innymi Korotkowa w Żywym trupie oraz Chleba w Niebieskim ptaku. Współpracę z tym teatrem Duwan-Torcow zakończył w 1914 roku, gdy przyjął stanowisko dyrektora-zarządcy Publicznego (Moskiewskiego) Teatru Dramatycznego w centrum Moskwy (ulica Karetny Riad). Pracował tam nieco ponad rok, a następnie przeszedł do drugiego studia Teatru Artystycznego, gdzie jednocześnie występował jako aktor i reżyserował przedstawienia. Jesienią 1917 r. powrócił do Kijowa, gdzie wznowił działalność teatr Sołowcowa. Duwan-Torcow był zwolennikiem

$2 \quad$ Ibidem, s. 277-278. 
metody Stanisławskiego, marzył o powstaniu w Kijowie teatru według założeń MChT i zorganizowaniu przy nim studiów dramatycznych. ${ }^{3}$

Izaak Duwan-Torcow był człowiekiem inteligentnym i błyskotliwym. Choć na scenie przychodziło mu grać głupków i prostaków, sam żywił głęboką awersję do głupoty, braku odpowiedzialności i samowoli. W 1920 r. zaoferowano mu funkcję naczelnego dyrektora Teatru Narodowego w Sofii i Duwan-Torcow opuścił opanowaną przez bolszewików Rosję. Od kwietnia 1920 r. do czerwca 1921 r. dokonał inscenizacji dwóch sztuk Aleksandra Nikołajewicza Ostrowskiego: Burzy (ros. Гроза) oraz Intratnej posady (ros. Доходное место). W 1921 r. wyjechał do Berlina, gdzie pracował jako aktor i reżyser, współzakładał też teatr małych form Maski, z którym gościnnie występował w różnych krajach Europy i Ameryki Południowej. W Berlinie, w rosyjsko-niemieckim teatrze małych form, wspólnie z Ryszardem Bolesławskim wyreżyserował sztukę Niebieski ptak (ros. Синяя птица). Od roku 1925 mieszkał w Paryżu, gdzie pracował jako reżyser i aktor w Teatrze Rosyjskim i brał aktywny udział w wieczorach komediowych i literacko-artystycznych. ${ }^{4}$

Życie na emigracji było dlań, podobnie jak i dla innych rosyjskich artystów, trudne. Podróżował wówczas po prawie całej Europie, występując w Bułgarii, Niemczech, Czechosłowacji, na Węgrzech, w Jugosławii, Szwajcarii, Anglii, Francji. Ostatnie lata życia spędził w Paryżu, gdzie osiadł jego brat, Siemion Ezrowicz Duwan. We Francji, gdzie Duwan-Torcow spędzał ostatni okres swojego życia, działali również inni znani karaimscy artyści, związani ze środowiskiem teatralnym, np. śpiewaczka operowa i operetkowa Marija Samojlowna Davydowa (Davidoff) czy Ludmiła (Ludmila) Iljiniczna Lopatto, pieśniarka i aktorka, która prowadziła w Paryżu znany kabaret „La Maisonette Russe”. Duwan-Torcow związał się z paryskim Teatrem Dramatu i Komedii, założonym w 1930 r. przez Olgę W. Baranowską. ${ }^{5}$ Zginął tragicznie, potrącony przez samochód 27 września 1939 r.

Przez całe życie nie uczestniczył wprawdzie aktywnie w religijnym życiu Karaimów, ale jego żona Wiera była także Karaimką, a on sam chętnie występował na wieczorach dobroczynnych organizowanych przez karaimskie organizacje charytatywne. Jego córka, Anna Duwan (1903-1969) była aktorką teatrów ukraińskich i rosyjskich. Syn, Ilja Duwan (1898-1976) również poświęcił

$3 \quad$ Ibidem, s. 278-279.

4 Por. Germanova, Mariâ, Moj larec s dragocennostâmi. Vospominaniâ. Dnevniki. Moskva 2012, s. 366.

$5 \quad$ Ibidem, s. 366. 
się karierze aktorskiej i reżyserskiej. Poszukując nowych środków wyrazu artystycznego, zbliżył się do modnych w owym czasie idei antropozoficznych. Związał się z teatrem w szwajcarskim Dornach. Tuż po wojnie wykładał i prowadził kursy w Niemczech (a także w Holandii, Norwegii i Austrii), skąd wkrótce przeniósł się z powrotem do Szwajcarii i osiadł w Bernie, gdzie w 1947 roku założył ze swoją żoną, Idą Duwan-Nater, pierwszy tzw. Zimmertheater. Pozostał tam już do końca życia. ${ }^{6}$ Najmniej wiadomo o drugiej córce Duwana-Torcowa, Tamarze Duwan (1896-?), która również była aktorką. ${ }^{7}$

\section{Duwan-Torcow i rosyjski teatr MChT (MChAT) w Czechosłowacji}

W czeskiej prasie nazwisko Duwana-Torcowa pojawiło się już w 1906 r., gdy „Národní listy” poinformowały o wystawieniu przez teatr przy Komitecie Piśmienności w Kijowie pod dyrekcją Duwana-Torcowa dramatu Františka Adolfa Šuberta pt. Żniwa (czes. Žně) w rosyjskim tłumaczeniu Václava Vondráka. Gazeta podała, że inscenizacja ta była udana. ${ }^{8}$

Rosyjska wojna domowa wywarła olbrzymi wpływ na rosyjską scenę teatralną, której liczni przedstawiciele osiedlili się w różnych częściach Europy. Fakt ten zauważyła również czeska prasa. Jak na początku października 1920 r. informował dziennik „Našinec”, wymieniając przy tym także Duwana-Torcowa:

„Ruští umělci rozprchli se po západní Evropě. [...]. V Bělehradě (v opeře) vystupuje A. V. Poljaková, v Lidovém domě v Sofii hrají Tarydina, Duvan-Torcov, Jurkovskij, Jakovlev, Šagorin a Nelidom." ${ }^{\prime \prime}$

W 1924 r. Duwan-Torcow, który był także aktorem filmowym, zagrał główną rolę w niemieckim filmie pt. Taras Bulba. Czeski periodyk „Filmový kurýr”

$6 \quad$ Por. http://biographien.kulturimpuls.org/detail.php?\&id=140 [15.10.2016 r.]; Kazas, Mihail Mihailovič i in. (red.), Karaimskaâ narodnaâ ènciklopediâ. Tom 5..., s. 280.

7 Sulimowicz, Anna, Tamara Duwan. Artystka niestała w uczuciach. „Awazymyz”, rok 24, nr 4 (41), grudzień 2013, s. 4-7.

8 Šubertovo drama „Žně”, „Národní listy”, rok 46, nr 36, 06.02.1906, s. 3.

9 "Rosyjscy artyści rozproszyli się po Europie Zachodniej. [...]. W Belgradzie (w operze) występuje A. W. Poliakowa, w Domu Ludowym w Sofii grają Tarydina, Duwan-Torcow, Jurkowskij, Jakowlew, Szagorin i Nelidom.” Zob. „Našinec”, rok 56, nr 224, 02.10.1920, s. 4. 
w 1928 r. donosił, że obraz ten ma stanowić materiał studyjny dla przygotowywanego amerykańskiego filmu na ten sam temat. ${ }^{10}$

Wśród rosyjskich zespołów teatralnych, działających w międzywojennej Czechosłowacji, szczególne miejsce zajmował Moskiewski Teatr Artystyczny (ros. Московский художественный театр). Założony w 1898 roku, swoją nazwę uzyskał w 1901 roku, w 1919 roku dodano w nazwie przymiotnik Akademicki (ros. Московский художественный академический театр), ale i później często używano poprzedniej krótszej nazwy. Po raz pierwszy czeska publiczność mogła obejrzeć gościnne występy Moskiewskiego Teatru Artystycznego w kwietniu 1906 r. głównie dzięki inicjatywie Jaroslava Kvapila ${ }^{11}$. Członkowie MCHT między 6 a 9 kwietnia 1906 r. zaprezentowali na scenie Teatru Narodowego dramaty Car Fiodor Iwanowicz Aleksego Tołstoja, ${ }^{12}$ Wujaszek Wania ${ }^{13}$ Czechowa oraz $\mathrm{Na}$ dnie Gorkiego ${ }^{14}$, które odniosły tu wielki sukces. ${ }^{15}$

Rosyjska wojna domowa spowodowała rozpad MChAT-u. Pierwszym znaczącym zespołem, który w wyniku wydarzeń wojennych wyodrębnił się z macierzystego teatru, była tzw. grupa kaczałowska, zwana tak od nazwiska aktora Wasilija Iwanowicza Kaczałowa. Grupa ta 27 kwietnia 1921 r. przyjechała z gościnnymi występami do Pragi. ${ }^{16} \mathrm{~W}$ okresie od 2 maja do 7 czerwca 1921 r. zaprezentowała około czterdziestu przedstawień w Teatrze Miejskim na Vinohradach, który podówczas był jej sceną macierzystą ${ }^{17}$ Nowy sezon teatralny grupa kaczałowska rozpoczęła w Pradze 4 września 1921 r. przedstawieniem Trzy siostry, a następnie od 5 do 9 września grała tę sztukę także w Pilźnie. ${ }^{18}$ Praski

10 Taras Bulba v Americe. „Filmový kurýr”, rok 2, nr 40, 10.11.1928, s. 3. W artykule podano, że film został wyprodukowany w Polsce.

11 Jaroslav Kvapil (1868-1950), wybitny czeski poeta, dramaturg, tłumacz i reżyser teatralny.

12 Por. np.: Moskevská činohra. „Národní listy”, rok 46, nr 96, 07.04.1906, s. 3.

13 Por. np.: Moskevská činohra. „Národní listy”, rok 46, nr 97, 08.04.1906, s. 4.

14 Por. np.: Moskevská činohra. „Národní listy”, rok 46, nr 99, 10.04.1906, s. 3.

15 O pierwszym wyjeździe MChAT do Pragi zob. np. Velemanová, Věra, MCHAT jako náš problém (Na okraj pripravované výstavy o pobytech MCHAT na našem územípř́spěvek ke 100. výroči MCHAT). „Divadelní revue”, rok 9, nr 2, 1998, s. 4-5.

16 Kronika kulturního, védeckého a společenského života ruské emigrace v Československé republice. Díl I. 1919-1929 / Hronika kul'turnoj, naučnoj i obŝsestvennoj žizni russkoj èmigracii $v$ Čehoslovackoj respublike. Tom I. 1919-1929. Praha/Praga: Slovanský ústav AV ČR / Slavânskij institut AN ČR, 2000, s. 45.

17 Šverubovič, Vadim, O starom Hudožestvennom teatre. Moskva: Iskusstvo, 1990, s. 323.

$18 \quad$ Ibidem, s. 336. 
sezon teatralny grupa zakończyła przedstawieniem Hamleta 10 października 1921 r. Następnie w dniach 14-17 października gościła w Bratysławie, po czym wyjechała do Wiednia. ${ }^{19}$

W początkach maja 1921 r. Duwan-Torcow jako członek Moskiewskiego Teatru Artystycznego, a także jego żona Wiera Duwan, syn Ilja Duwan i Jelizawieta Duwan ${ }^{20}$ otrzymali w czechosłowackiej ambasadzie w Sofii wizy wyjazdowe do Czechosłowacji. ${ }^{21}$ Nie udało się jednak stwierdzić, czy ostatecznie I. Duwan-Torcow i jego rodzina występowali na scenie podczas tournée grupy kaczałowskiej MCHT w 1921 r. Nader prawdopodobnym jest, że Duwan-Torcow nie brał aktywnego udziału w przedstawieniach, gdyż w zachowanych dokumentach jego nazwisko nie figuruje wśród wykonawców. ${ }^{22}$

W 1923 r. z inicjatywy Marii Nikołajewny Germanowowej i Nikołaja Osipowicza Massalitinowa powstał w Pradze nowy zespół teatralny. Była to tzw. praska grupa MChT (MChAT). Stolica Czechosłowacji pozostawała jej siedzibą do roku 1927, choć w nazwie przymiotnik „praska” grupa zachowała aż do $1935 \mathrm{r}^{23}$ To właśnie w ramach tej grupy Duwan-Torcow działał w Czechosłowacji na przełomie lat 1925/1926. Z jego karty ewidencyjnej wynika, że był tu oficjalnie zameldowany w okresie od 6 października 1925 r. do 16 marca 1926 r. Artysta, który wtedy posiadał adres stałego zamieszkania w Sofii, w Bułgarii, mieszkał w Pradze w dzielnicy Vinohrady, stosunkowo niedaleko od tutejszego Teatru Miejskiego, ówczesnej sceny macierzystej praskiej grupy MChT. Początkowo był zameldowany przy ulicy Šumavskiej 16 (do początku listopada

$19 \quad$ Ibidem, s. 343.

20 Jelizawieta Mojsiejewna Duvan (1899-1969) przez dwa lata pracowała w grupie teatralnej Duwana-Torcowa, który był wujem jej męża, zob. http://www.karaims. com/page.php?cod=ru\&page $=257 \&$ node $=244 \& p=299$ [15.05.2016 r.].

21 Národní archiv Praha, Policejní ředitelství Praha II - všeobecná spisovna 1921-1930, pudło nr 553, Duvan-Torcov, dokument nr 1.

22 W maju 1921 r. grupa kaczałowska wystawiła w Teatrze Miejskim następujące przedstawienia: Inejvětš́ chytrák se spálí (pol. I koń się potknie) A. Ostrowskiego, $\mathrm{Na}$ dně (pol. Na dnie) M. Gorkiego, Bratři Karamazovi (pol. Bracia Karamazow) według F. Dostojewskiego, Podzimni housle (pol. Jesienne skrzypce) I. Surguczewa, Tři sestry i Višňový sad (pol. Trzy siostry i Wiśniowy sad) A. Czechowa oraz Ve spárech života (tytuł oryg. Livet $i$ vold) K. Hamsuna. Zob. Divadelní oddělení Národního muzea, divadelní cedule pro rok 1921, sygn. P-XI, nr inw. H6C-242.

23 Por. Inov, Igor, Literaturno-teatral'naâ, koncertnaâ deâtel'nost' bežencev-rossiân v Čehoslovakii (20-40 gody 20-ogo veka). Tom 1. Praha: Národní knihovna ČR - Slovanská knihovna, 2003, s. 86-91. 
1925 r.), a następnie przy Slovenskiej 3. ${ }^{24} \mathrm{~W}$ urzędowych dokumentach Duwan-Torcow podał wówczas, że swoją ojczyznę opuścił podczas rewolucji w $1920 \mathrm{r}$. i że do Czechosłowacji przyjechał z Paryża jako aktor Moskiewskiego Teatru Artystycznego. ${ }^{25} \mathrm{~W}$ jego dokumencie tożsamości, wydanym w marcu $1923 \mathrm{r}$. w Wiedniu na okres - jak to było praktykowane - jednego roku, odnotowano, że w kwietniu tego roku przebywał w Szwajcarii w kantonie Berno, następnie przez Bazyleę dotarł do Niemiec, gdzie przebywał we Frankfurcie nad Menem, Lipsku, Bad Kissingen i Grünwaldzie. ${ }^{26}$ W lutym 1926 r. w Czechosłowacji wydano mu również roczną wizę do piętnastu krajów europejskich i Stanów Zjednoczonych. ${ }^{27}$

Praska grupa MChT rozpoczęła sezon teatralny 14 grudnia 1925 r. w Teatrze Miejskim na Vinohradach sztuką A. Ostrowskiego Chudoba cti netratí (ros. Бедность не порок), w której zagrał także Duwan-Torcow. ${ }^{28}$ „Národní listy” w wydaniu z 13 grudnia 1925 r. napisały o tym przedstawieniu:

„Pražská skupina Moskevského Uměl[eckého] divadla, která se natrvale usídlila u nás a pořádala $\mathrm{v}$ minulé saisoně řadu zajímavých představení, vystoupí na scéně Městského divadla zítra v dosud nehrané veselohře $\mathrm{A}$. N. Ostrovského «Chudoba cti netratí». Umělci, kteří interpretací ruských typů nemají sobě rovných, budou míti príležitost předvésti novou řadu zajímavých postav z ruského kupeckého prostředí z polovice XIX. století. [...]. V hlavních rolích Kryžanovská, Grečová, Dněprová, Duvan-Torcov, Pavlov, Bodgenov, Serov, Komisarov a ostatní členové družiny”. ${ }^{29}$

24 Národní archiv Praha, Policejní ředitelství Praha II - evidence obyvatelstva, Izaak Duvan-Torcov.

25 Národní archiv Praha, Ministerstvo zahraničních věcí - Ruská pomocná akce, pudło nr 91, Izaak Duvan-Torcov, dokument nr 1-2.

26 Národní archiv Praha, Ministerstvo zahraničních věcí - Ruská pomocná akce, pudło nr 91, Izaak Duvan-Torcov, Identitätschein, dokument nr 3-4.

27 Národní archiv Praha, Policejní ředitelství Praha II - všeobecná spisovna 1921-1930, pudło nr 553, Duvan-Torcov, dokumenty nr 3-7.

28 Pražská skupina moskevského Umèl. divadla. „Národní listy”, rok 65, dodatek do nr. 334, 06.12.1925 r., s. 10.

29 „Praska grupa Moskiewskiego Teatru Art[ystycznego], która na stałe osiedliła się u nas i w ubiegłym sezonie odegrała serię ciekawych przedstawień, wystąpi jutro na scenie Teatru Miejskiego z niewystawianą dotąd komedią A. N. Ostrowskiego „Bieda nie jest występkiem”. Artyści, którzy w interpretacji rosyjskich charakterów nie mają sobie równych, będą mieć okazję zaprezentować nowy szereg ciekawych postaci z rosyjskiego środowiska kupieckiego z połowy XIX wieku. [...] W rolach głównych Kryżanowska, Greczowa, Dnieprowa, Duwan-Torcow, Pawlow, 
Powtórkę tej sztuki w Teatrze Miejskim widzowie mogli jeszcze zobaczyć m.in. 17 stycznia 1926 r. ${ }^{30}, 27$ stycznia 1926 r. ${ }^{31}$ czy 19 lutego 1926 r. ${ }^{32}$ Oprócz tego przedstawienia znacznym sukcesem cieszyła się także inscenizacja dramatu Żywy trup L. Tołstoja, którą Teatr Miejski na Vinohradach zaprezentował po raz ostatni 20 lutego 1926 r. Przedstawienia praskiej grupy Moskiewskiego Teatru Artystycznego czechosłowaccy widzowie mogli w następnych dniach podziwiać nie tylko w Pradze w Teatrze Miejskim, gdzie odbywała się większość przedstawień, ale także poza stolicą - grupa ruszyła z występami na Morawy i na Slowacje. ${ }^{33}$

Na przełomie lat 1925/1926, gdy występował z praską grupą, Duwan-Torcow kilka razy odwiedził także Pilzno w zachodnich Czechach. 21 listopada 1925 r. wystąpił tu w Ożenku M. Gogola w reżyserii Nikołaja O. Massalitinowa. Ówczesna prasa podkreślała, że treść sztuki tak opracowano, by czescy widzowie mogli ją zrozumieć bez najmniejszych problemów. W Pilźnie sztuka cieszyła się ogromnym zainteresowaniem $\mathrm{z}$ racji tego, że było to jedyne przedstawienie rosyjskiego zespołu teatralnego. ${ }^{34}$

Duwan-Torcow ponownie zagościł w Pilźnie w lutym 1926 r. Praska grupa MCHT zaprezentowała tu 23 lutego 1926 r. Żywego trupa Tołstoja. O występie Duwana-Torcowa w tym przedstawieniu dowiadujemy się z recenzji anonimowego autora, który o całym spektaklu wyraża się z wielką aprobatą, zaznaczając już na początku swojej relacji:

„Večer, který připravil dramatický soubor moskevských umělců $v$ úterý našemu divadelnímu obecenstvu, byl požitkem, na který se nezapomíná. Ryzí, nefalšované umění vyzařovalo $\mathrm{z}$ každé scény a neváhám říci i z každého jednotlivce. To nebylo divadlo, to život sám šel kolem nás a jímal svou opravdovostí.”35

Bodgenow, Serow, Komisarow oraz pozostali członkowie zespołu”. Pražská skupina Moskevského Umèl. divadla. „Národní listy”, rok 65, nr 341, 13.12.1925, s. 13.

30 Ruské umèlecké divadlo v Praze. „Národní politika”, odpolední vydání, rok 44, nr 16, 16.01.1926, s. 5.

31 Městské divadlo Král. Vinohrad. „Národní politika”, odpolední vydání, rok 44, nr 27, 27.01.1926, s. 4.

32 Městské divadlo Král. Vinohrad. „Národní politika”, odpolední vydání, rok 44, nr 50, 19.02.1926, s. 4.

33 Moskevské umélecké divadlo. „Národní politika”, odpolední vydání, rok 44, nr 46, 15.02.1926, s. 5 .

34 „Český deník”, rok 14, nr 319, 21.11.1925, s. 4.

35 "Wieczór, przygotowany przez zespół dramatyczny artystów moskiewskich we wtorek dla publiczności naszego teatru, był przyjemnością, o której się nie zapomina. 
W dalszej części relacji autor w równie entuzjastycznym tonie chwali grę Duwana-Torcowa:
„Druhý obraz «U cikánů» byl pln nenucené živosti a jarého veselí. V něm zvláště Máša (Grešová) a J. Makarovič (Zelickij) dodali hře krásného rytmu. Avšak výkon I. E. Duvana-Torcova (Afremov) náležel beze sporu k nejlepším celého večera. Alkoholem zmožený válel se líně ve vzduchu i na lavici přimhuřuje oči jako v polospánku, ale jak se ozvaly struny kythar, hrály mu všechny žilky v rukou i nohou a do taktu dupal, až se kolem prášilo. A př̀i tom jako medvěd si pobručoval a po děvčatech se olizoval. Výkon bez nadsázky jedinečný.”’

Poza Pilznem praską grupę Moskiewskiego Teatru Artystycznego podejmował na swej scenie także np. Teatr Miejski w Morawskiej Ostrawie, gdzie 16 lutego 1926 r. wystawiono Biednost' nie porok. Duwan-Torcow zagrał tu rolę Gordieja Karpycza Torcowa. ${ }^{37}$ Grupa zagościła w Ostrawie ponownie w roku 1931, prezentując 28 marca Rewizora Gogola ${ }^{38}$, a 29 marca Ożenek tego samego autora $^{39}$ oraz Dni Turbinów Bułhakowa ${ }^{40}$. Jednak w obsadzie żadnej z nich nie znajdujemy już nazwiska Duwana-Torcowa.

Czysta, niefałszowana sztuka promieniowała z każdej sceny, a nie zawaham się powiedzieć, że i z każdej osoby. To nie był teatr, to samo życie szło obok nas i ujmowało nas swą prawdziwością.” Moskevští v Plzni. Živá mrtvola. „Český deník”, rok 15, nr 61, 02.03.1926, s. 4.

„Druga scena «U cyganów» była pełna życia i niewymuszonej wesołości. Zwłaszcza Masza (Greszowa) i J. Makarowicz (Zelickij) dodali przedstawieniu piękny rytm. Jednakże to występ I. E. Duwana-Torcowa (Afremow) należał bez wątpienia do najlepszych z całego wieczoru. Zmożony alkoholem leniwie przemieszczał się z miejsca na miejsce i przesiadywał na ławce, mrużąc oczy niczym w półśnie, ale jak tylko odezwały się struny gitar, pulsowały mu wszystkie żyłki na rękach i nogach i tupał do taktu, aż się kurzyło dookoła. Przy tym pomrukiwał sobie niczym niedźwiedź i ślinka mu ciekła na widok dziewcząt. Wykonanie absolutnie wyjątkowe." Moskevští v Plzni. Živá mrtvola, „Český deník”, rok 15, nr 61, 02.03.1926, s. 4.

37 http://www.ndm.cz/cz/hoste/inscenace/3482-pohostinske-predstaveni-mchatmoskva-a-n-ostrovskij-chudoba-cti-netrati/ [06.05.2016 r.]. http://www.ndm.cz/cz/hoste/inscenace/3598-pohostinske-predstaveni-mchatmoskva-n-v-gogol-revizor/ [06.05.2016 r.].

39 http://www.ndm.cz/cz/hoste/inscenace/3599-pohostinske-predstaveni-mchatmoskva-n-v-gogol-zenitba/ [06.05.2016 r.].

40 http://www.ndm.cz/cz/hoste/inscenace/3600-pohostinske-predstaveni-mchatmoskva-michail-bulgakov-dni-turbinovych/ [06.05.2016 r.]. 
Pod koniec sierpnia 1930 r. czeska prasa donosiła, że planowano w najbliższym czasie reorganizację i rozszerzenie praskiej grupy MChAT. Grupa, wśród członków której był wymieniany także Duwan-Torcow, miała mieć swą siedzibę w Jugosławii, w Belgradzie, skąd zamierzano organizować wyjazdy na gościnne występy w innych krajach słowiańskich. ${ }^{41}$

Wróćmy jednak do roku 1926, gdy Duwan-Torcow występował w Czechosłowacji z praską grupą MCHT. Pod koniec lipca „Národní listy” pisały o grupie:

"Je to ona družina, která se odloučila od ostatního tělesa Moskevského Uměleckého divadla a s pí. M. Germanovou a s režisérem Massalitinovem v čele našla v Praze dočasný útulek a základnu pro svou další činnost. Přisvojila si již na trvalo přívlastek ,Pražských Moskvanư a lze říci, že dělá Praze všecku čest v cizině, kde dlí již od sklonku letošní zimy."²

Autor artykułu zaznaczył, że wśród nowych członków grupy, którzy wzmocnili jej skład jesienią 1925 r., znalazł się także I. Duwan-Torcow. Pod koniec lutego grupa odbyła tournée po Europie, występując w takich miastach, jak: Budapeszt, Berlin, Paryż, Zurych, Bazylea, Berno, Genewa, po czym powróciła do Paryża. W Pradze pojawiła się ponownie dopiero w 1927 r. ${ }^{43}$ Artyści MChAT brali udział także w pozateatralnych wydarzeniach kulturalnych, takich jak „Dzień Tatiany” zorganizowany przez Zjednoczenie Komitetów Akademickich w Pradze w Domu Narodowym na Smíchowie 25 stycznia 1926 r. W imprezie wzięła udział także praska grupa MCHT a moderatorem występu kabaretowego był Izaak Duwan-Torcow. ${ }^{44}$ Igor Inow podaje, że Duwan-Torcow znajdował się także na liście artystów Rosyjskiej Sceny Kameralnej w Pradze. ${ }^{45}$

41 Pražská skupina Moskevského umèleckého divadla. „Národní politika”, rok 48, wydanie popołudniowe, nr 236, 28.08.1930, s. 2; Reorganisace pražské skupiny Moskevského Uméleckého divadla v Jugoslávii. „Český deník”, rok 19, nr 238, 30.08.1930, s. 5.

42 „Jest to grupa, która wydzieliła się z zespołu Moskiewskiego Teatru Artystycznego i z panią M. Germanową i reżyserem Massalitinowem na czele znalazła w Pradze tymczasowe schronienie oraz bazę dla swojej dalszej działalności. Przylgnął już do niej na stałe przydomek 'Praskich Moskwian' i można powiedzieć, że przynosi Pradze zaszczyt za granicą, gdzie przebywa już od końca tegorocznej zimy.” Pražská skupina Moskevských. „Národní listy”, rok 66, Večerník Národ, nr 203, 27.07.1926, s. 4.

43 Ibidem

44 Tat'ânin den'v Prage. „Rul”, rok 7, Berlin, Wochentag-Ausgabe, nr 10 (1556), 15.01.1926.

45 Inov, Igor, op. cit., s. 189, 249. 


\section{Zakończenie}

Po 1926 r. Izaak Duwan-Torcow prawdopodobnie już nie pojawił się na terenie Czechosłowacji. Z niewielu zachowanych dokumentów wynika jednak, że jego talent aktorski i profesjonalizm zostały zauważone tak przez krytykę, jak i przez czeskich widzów, którzy chętnie oglądali gościnne występy praskiej grupy MCHT na przełomie lat 1925-1926, zarówno w Teatrze Miejskim na praskich Vinohradach, scenie macierzystej tej grupy rosyjskich artystów, jak i w teatrach w innych miastach. Choć jego pobyt w Czechosłowacji ograniczył się do kilku miesięcy, można zaliczyć Izaaka Duwana-Torcowa do grupy sześćdziesięciu osób pochodzenia karaimskiego, której obecność na terenie międzywojennej Czechosłowacji jest udokumentowana. Czeski epizod w jego karierze stanowi drobny, ale nie pozbawiony znaczenia element dziejów rosyjskiego teatru na emigracji.

\section{Archiwa}

Divadelní oddělení Národního muzea, cedule pro rok 1921, sygn. P-XI, nr inw. H6C-242.

Divadelní oddělení Národního muzea, cedule pro rok 1922, sygn. P-XI, nr inw. H6C-243. Národní archiv Praha, Národní archiv Praha, Ministerstvo zahraničních věcí - Ruská pomocná akce, pudło nr 91, Izaak Duwan-Torcow.

Národní archiv Praha, Policejní ředitelství Praha II - evidence obyvatelstva, Izaak Duwan-Torcow.

Národní archiv Praha, Policejní ředitelství Praha II - všeobecná spisovna 1921-1930, pudło nr 553, Duwan-Torcow.

\section{Literatura}

Běloševská, Ljubov, Kronika kulturního, vědeckého a společenského života ruské emigrace $v$ Československé republice. Díl I. 1919-1929 / Hronika kul'turnoj, naučnoj i obŝestvennoj žizni russkoj èmigracii v Čehoslovackoj respublike. Tom I. 1919-1929. Praha/Praga: Slovanský ústav AV ČR / Slavânskij institut AN ČR, 2000.

Běloševská, Ljubov, Kronika kulturního, vědeckého a společenského života ruské emigrace $v$ Československé republice. Díl II. 1930-1939 / Hronika kul'turnoj, naučnoj i obŝestvennoj žizni russkoj èmigracii $v$ Čehoslovackoj respublike. Tom II. 1930-1939. Praha/Praga: Slovanský ústav AV ČR / Slavânskij institut AN ČR, 2001.

Brej, Andrej, Russkij teatr v Prage. [w:] Sergej Porfirevič Postnikov (red.): Russkie v Prage 1918-1928 gg. Praha: Národní knihovna, 1995 [przedruk publikacji z 1928 r.], s. 322-329.

Dubrovina, Tat'âna, Materialy k istoii pražskoj grupy MHAT. [w:] Marija Magidová i in. (red.): Russkaâ, ukrainskaâ i belorusskaâ èmigraciâ v Čehoslovakii meždu dvumâ mirovymi vojnami. Rezul'taty i perspektivy provedennyh issledovanij. Fondy Slavânskoj biblioteki 
i pražskih arhivov / Russian, Ukrainian and Belorussian Emigration between the World Wars in Czechoslovakia. Results and Perspectives of Contemporary Research. Holdings of the Slavonic Library and Prague Archives. Tom 2. Praha: Národní knihovna ČR Slovanská knihovna, 1995, s. 762-767.

Germanova, Mariâ, Moj larec s dragocennostiâmi. Vospominaniâ. Dnevniki, Moskva: Russkij Put', 2012.

Inov, Igor, Literaturno-teatral'naâ, koncertnaâ deâtel'nost' bežencev-rossiân v Čehoslovakii (20-40 gody 20-ogo veka). Tom 1. Praha: Národní knihovna ČR - Slovanská knihovna, 2003.

Kazas, Mihail Mihailovič i in (red.), Karaimskaâ narodnaâ ènciklopediâ. Tom 5. Kul'tura krymskich karaimov (tûrkov). Sankt-Peterburg: Moskovskaâ obŝestvennaâ organizaciâ „Kul'turno-prosvetitel'skoe obŝestvo karaimov”, „Sankt-Peterburgskij nacional'no-kul'turnyj centr karaimov", 2006.

Sulimowicz, Anna, Tamara Duwan. Artystka niestała w uczuciach. „Awazymyz”, rok 24, nr 4 (41), grudzień 2013, s. 4-7.

Šverubovič, Vadim, O starom Hudožestvennom teatre. Moskva: Isskustvo, 1990.

Tat'ânin den'v Prage. „Rul'” 7, Berlin, Wochentag-Ausgabe, nr 10 (1556), 15.01.1926.

Vagapova, Natal'â Mihajlovna, Russkaâ teatral'naâ èmigraciâ v Central'noj Evrope i na Balkanah. Očerki. Sankt-Peterburg: Aleteja, 2007.

Velemanová, Věra, MCHAT jako náš problém (Na okraj pripravované výstavy o pobytech MCHAT na našem území - přispěvek ke 100. výroči MCHAT). „Divadelní revue”, rok 9, nr 2, 1998, s. 3-18.

Velemanova, Vera, Moskovskij Hudožestvennyj teatr - točki soprikosnoveniâ s Pragoj (wyd. G. Al’bertova). Praga: Teatral'nyj Institut v Prage, 1998 [katalog wystawy].

\section{Źródła internetowe}

http://www.karaims.com/page.php?cod=ru\&page=257\&node=244\&p=299 [15.05.2016]. http://www.ndm.cz/cz/hoste/inscenace/3482-pohostinske-predstaveni-mchat-moskvaa-n-ostrovskij-chudoba-cti-netrati/ [06.05.2016]. http://biographien.kulturimpuls.org/detail.php?\&id=140 [15.10.2016]. 


\section{Aneks}

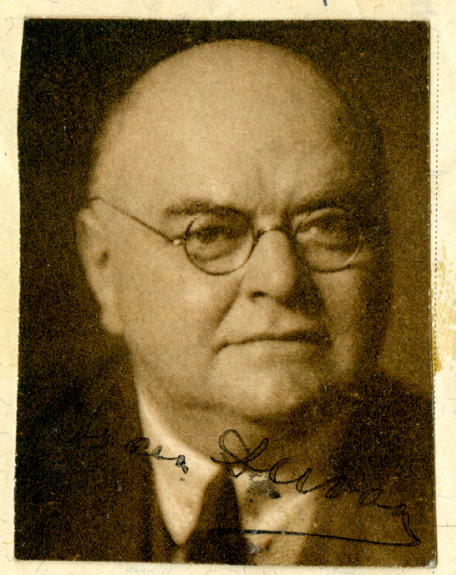

Ryc. I. Izaak Duwan-Torcow. Fotografia portretowa z autografem. Národní archiv Praha, Policejní ředitelství Praha II - všeobecná spisovna 1921-1930, pudło nr 553, Duvan-Torcov, nr 7.

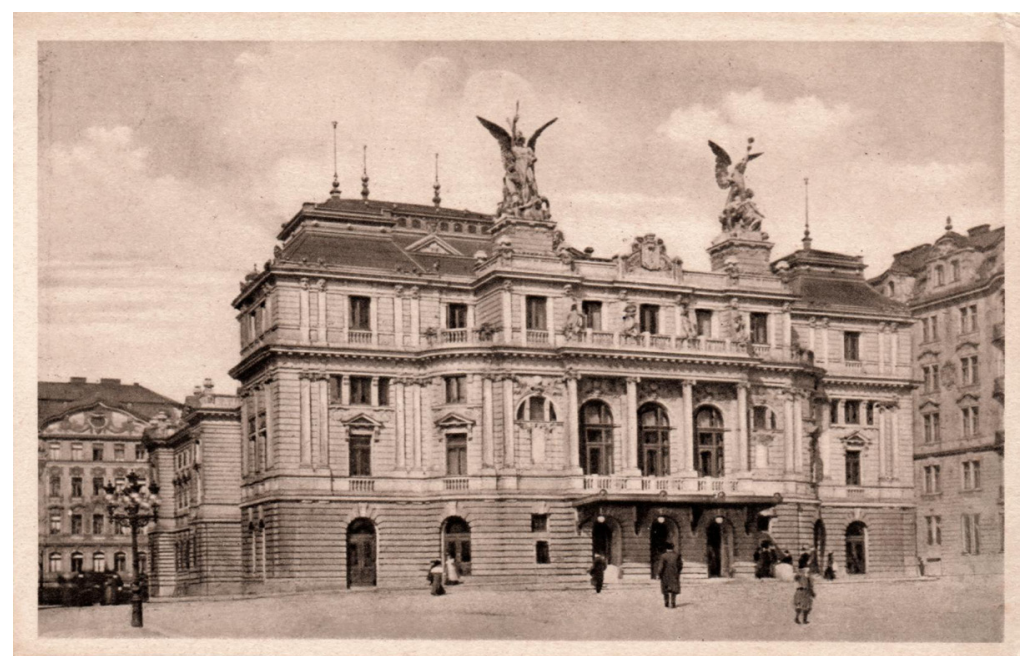

Ryc. 2. Teatr Miejski na Winogradach w Pradze. Pocztówka z pierwszej ćwierci XX w. Archiwum prywatne Anastasii Kopřivovej, Praga. 